the purpose, and nothing said in Cairo will change that. It would be out of tune with the principles of the UN Charter, which does not allow intervention in the domestic affairs of member states, to make a fuss on this issue.

That, sadly, in not the only red herring on the agenda. In the best UN tradition, the drafting committees have set out to cure all the world's ills at Cairo. The result is that the draft declaration is laden with contentious issues not strictly relevant to population stability. Sustainable development is a recurring theme. There are even specific recommendations on the way in which the debts of developing-country governments should be handled. It is to be hoped that the minor rows that these will generate will not so distract the Cairo conference that the opportunity for strengthening the impending global demographic transition will be lost.

\section{Courteous Linus Pauling}

One pity of Linus Pauling's death is that even vitamin C could not keep him living longer.

THE death last week of Linus Pauling at 93 is a sad business for everybody. He was one of the now few surviving links with that heroic age when modern science was fashioned from the bare essentials of quantum mechanics as made plain in the 1920s at Copenhagen, Göttingen and Heidelberg. With a few deft monographs, and in particular, with The Nature of the Chemical Bond, he induced a whole generation of young people to take seriously the notion that the properties of molecules could be calculated. By carrying the message of quantum mechanics to the New World, he did for chemistry what Oppenheimer did for physics.

But quantum chemistry, for Pauling, was merely incidental to his chief interest, the exercise of his unparalleled sense of three-dimensional geometry in the understanding of how molecules, especially large molecules, are constructed. Watson and Crick were understandably anxious, in the early 1950 s, that Pauling, from an earlier generation, might be the first to get the structure of DNA. It is still a mystery that he did not. Versatility was his strong suit.

And iconoclastic independence. There is great relish in the tale of Pauling's arrival at a tuxedo dinner at President John F. Kennedy's White House straight from the lines of an anti-nuclear demonstration outside the railings. Yet he was not an embittered iconoclast, but one of great charm and courtesy. And who, having seen him lecture on some topic close to his scientific interest, will not still be infected with his enthusiasm for understanding, and can have forgotten those great arms waving like semaphores to tell the world what fun it all is?

Pauling's last exercise in iconoclasm, his advocacy of megadoses of vitamin $\mathrm{C}$ as a defence against cancer and other ills, is in a different case. The charitable judgement of that episode is that Pauling never really buckled down to accepting the complexities of the evidence usually required to sustain a hypothesis in biology. (Even so, there is no reason why the $\mathrm{BBC}$ should have labelled him a heretic - see below.) But it is important that concern with the effects of vitamin $\mathrm{C}$ did not blind Pauling to the rest of science. When quasi-crystals were discovered, he was one of the first with an explanation. To the end, last week, he remained alert, seeing the fun in things. He will be missed.

\section{Heresy at the BBC}

The British Broadcasting Corporation deserves no credit for a meretricious series of television films.

THE British Broadcasting Corporation (BBC), not to be mistaken for an agency of the British government, is one of the world's outstanding broadcasting organizations. Over the years, it has helped to carry authentic news of world events to parts of the world deprived thereof, and has entertained and instructed its domestic audience in a manner that is often admired (and imitated). On the whole, it has done well by science. BBC television, for example, invented the idea that working scientists could be made to explain what they were about to intelligent interlocutors in longish programmes consisting of several weekly parts.

Now, and sadly, the BBC is scrambling like many other British institutions to 'reposition' itself in British society and in the world. (Although the government has recommended that the BBC's right to collect a 'licence fee' from every British owner of a television receiver, which is where the money comes from, parliament has still to debate the issue.) Presumably as part of that exercise, the BBC has just broadcast a remarkable series of television programmes under the rubric of "Heretic" which does science and the $\mathrm{BBC}$ itself no service.

The idea is simple, and intrinsically entertaining. Invite an iconoclast to outline an eccentric theory, and then invite more orthodox people to say why they do not agree. The iconoclast and his critics never meet face to face. The result is that both the iconoclast and his (or her, but there were no women heretics in the BBC's sample of six) critics are made to seem foolish, the former because of the inevitable obsessiveness that shows through, the latter because disembodied statements of the general opinion inevitably sound pompous. Good fun is had by all.

The BBC's iconoclasts included the authors of 'cold fusion', Dr Jacques Benveniste (who believes that water has a memory, and with whom Nature has had several brushes), and the late Linus Pauling (see above). Dr Rupert Sheldrake (who holds that morphogenetic fields condition the world we live in) was another. The programmes asked, in effect, why science will not take seriously the questions asked by manifestly honest people. The answer is, of course, that the iconoclasts have always failed to demonstrate that their questions are meaningful. But the concept of the 'good question' would no doubt have diminished the general audience for these programmes. Yet when the renewal of the BBC's charter is eventually debated, this meretricious exercise will no doubt be quoted as another public service done. 